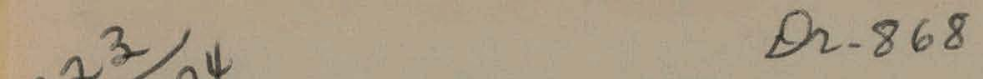

RFP-2303

June 20, 1974

RFP-2303

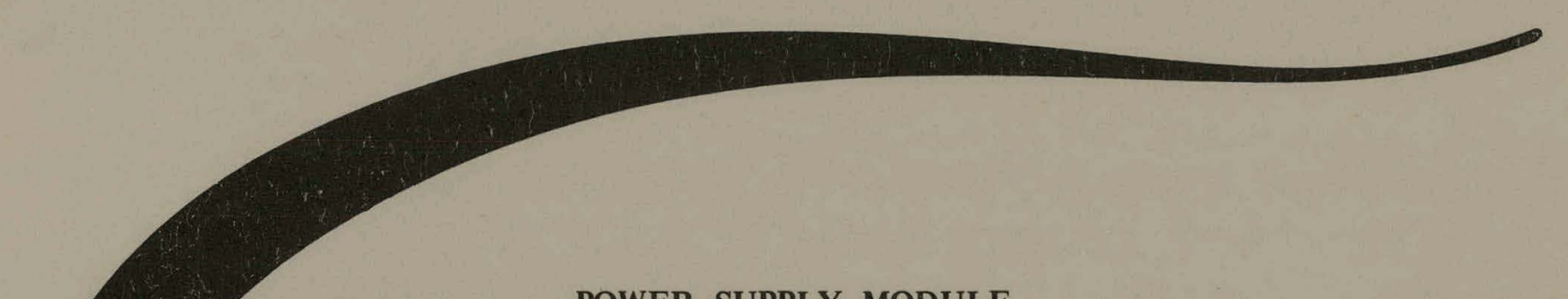

POWER SUPPLY MODULE

Bradley E. Martin

Modules for Radiation Detection Systems and related items will be grouped in a series of reports beginning with RFP-2300 through RFP-2325. RFP-2303 represents a continuation in the series.

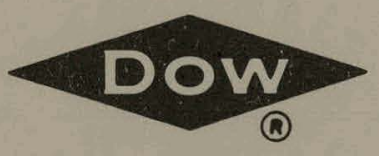

DOW CHEMICAL U.S.A.

ROCKY FLATS DIVISION

P. O. BOX 888

GOLDEN, COLORADO 80401

U.S. ATOMIC ENERGY COMMISSION

CONTRACT AT(29-1)-1106 


\section{DISCLAIMER}

This report was prepared as an account of work sponsored by an agency of the United States Government. Neither the United States Government nor any agency Thereof, nor any of their employees, makes any warranty, express or implied, or assumes any legal liability or responsibility for the accuracy, completeness, or usefulness of any information, apparatus, product, or process disclosed, or represents that its use would not infringe privately owned rights. Reference herein to any specific commercial product, process, or service by trade name, trademark, manufacturer, or otherwise does not necessarily constitute or imply its endorsement, recommendation, or favoring by the United States Government or any agency thereof. The views and opinions of authors expressed herein do not necessarily state or reflect those of the United States Government or any agency thereof. 


\section{DISCLAIMER}

Portions of this document may be illegible in electronic image products. Images are produced from the best available original document. 


\section{LEGAL NOTICE}

This report was prepared as an account of work sponsored by the United States Government. Neither the United States nor the United States Atomic Energy Commission, nor any of their employees, nor any of their contractors, subcontractors, or their employees, makes any warranty, expressed or implied, or assumes any legal liability or responsibility for the accuracy, completeness or usefulness of any information, apparatus, product or process disclosed, or represents that its use would not infringe privately owned rights.

Printed in the United States of America

Available from the

National Technical Information Service

U. S. Department of Commerce.

Springfield, Virginia 22151

Price: Printed Copy $\$ 4.00$ Microfiche $\$ 1.45$ 
Printed

June 20, 1974
RFP-2303

UC-41 HEALTH AND SAFETY

TID-4500-R60

\title{
POWER SUPPLY MODULE
}

\author{
Bradley E. Martin
}

Product and Health Physics Research

ELECTRONICS GROUP

Modules for Radiation Detection Systems and related items will be grouped in a series of reports beginning with RFP-2300 through RFP-2325. RFP-2303 represents a continuation in the series.

NOTICE

This report was prepared as an account of work This report was prepared astes avernment. Neither the United States nor the United States Atomic Energy Co United States nor the United States Atomic Energy Commission, hor any of their employees, nor any of their contractors, subcontractors, or their employees, makes any warranty, express or implied, or assumes any egal liability or responsibility for the accuracy, completeness or usefulness of any information, apparatus, product or process disclosed, or represents that its use would not infringe privately owned rights.
UUW CHEMICAL U.S.A. ROCKY FLATS DIVISION

P. O. $B O \times 888$

GOLDEN, COLORADO 80401

Prepared under Contract AT(29-1)-1106

for the

Albuquerque Operations Office

U. S. Atomic Energy Commission

\section{SUBJECT DESCRIPTORS}

Power Supply Modules Alpha Detection Systems Wound Counting Systems Gamma Spectrometers

Electronics

Monitoring Systems

Nuclear Instrumentation Bin 


\title{
CONTENTS
}

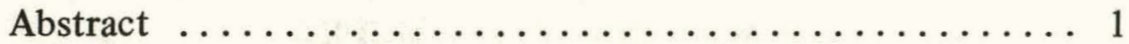

Introduction $\ldots \ldots \ldots \ldots \ldots \ldots \ldots \ldots \ldots \ldots \ldots \ldots \ldots$

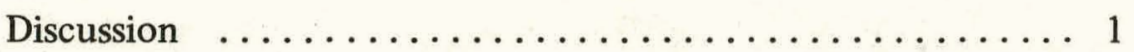

Description $\ldots \ldots \ldots \ldots \ldots \ldots \ldots \ldots \ldots \ldots$

Circuit Analysis $\ldots \ldots \ldots \ldots \ldots \ldots \ldots \ldots \ldots$

Operating Procedures $\ldots \ldots \ldots \ldots \ldots \ldots \ldots \ldots \ldots \ldots \ldots \ldots \ldots$

Servicing of Module $\ldots \ldots \ldots \ldots \ldots \ldots \ldots \ldots \ldots \ldots \ldots \ldots \ldots$

Illustrations $\ldots \ldots \ldots \ldots \ldots \ldots \ldots \ldots \ldots \ldots \ldots \ldots \ldots \ldots \ldots \ldots \ldots \ldots$
\end{abstract}




\title{
POWER SUPPLY MODULE
}

\author{
Bradley E. Martin
}

\begin{abstract}
In developing radiation detection instrumentation at Rocky Flats Division, a system concept using plug-in modules was planned. Losses of operational time due to maintenance are drastically reduced as a malfunctioning module can be replaced within minutes. Versatility is another advantage of the modular concept. A particular module can be used in many different system designs. A significant cost savings in system development can also be realized.
\end{abstract}

The power supply is housed in a two-wide Nuclear Instrumentation Bin (NIM-BIN) module. It provides +12 volts $\mathrm{DC}$ for electronic circuitry and 2.5 volts AC for light-emitting diode (LED) displays. The 12-volt DC regulator, an integrated circuit (IC), is packaged in a TO-3 case featuring low cost and high reliability. The power supply is used in a gross alpha-detection system and a medical wound-counting system.

\section{INTRODUCTION}

Described is a power supply which was developed for a gross alpha-detection system and a medical wound-counting system.

The power supply has importance because it powers the systems used for collecting data and analyzing the levels of radioactive contamination which might occur during plant activities. Under the Health Physics monitoring program at Rocky Flats Plant, concerted efforts are directed toward improvements in safety, state-of-the-art applications, and the reduction of operating costs.

\section{DISCUSSION}

\section{Description:}

Model 24370-11 is a power supply unit that can be used in a NIM-BIN to power modules requiring
+12 volts $\mathrm{DC}$ and 2.5 volts AC. Two specific applications for the power supply include a gross alpha-detection system and a medical woundcounting system.

The module in Figure $1^{*}$ shows the front panel which contains the on-off switch, an indicator lamp, and test points (TP).

The transformers and rectifiers are mounted on an extra-thick printed circuit board (PCB) (Figure 2). This arrangement simplifies the wiring and chassis layout.

At the rear panel (Figure 3), 117 volts AC enter the module, and a line fuse and IC regulator are mounted. At the bottom of the panel, the NIM-BIN connector feeds the output voltages into the bin-wiring system.

\section{Circuit Analysis:}

In Figure 4, the PCB contains T1, a 12.6-volt transformer and $\mathrm{BR} 1$, a bridge rectifier. The unregulated output voltage at Pin 14 is approximately 20 volts DC. Transformer T 2 provides 2.5 volts $\mathrm{AC}$ to Pins 5 and 12 . Ground 12 volts, 2.5 volts, and 117 volts are jumpered across the PCB to simplify the wiring.

In Figure 5, the overall wiring diagram shows Pins 2 and 4 of the PCB which receive 117 volts AC. The AC neutral is fed directly to Pin 41 of the NIM-BIN connector. The AC line is decoupled by the capacitor (C3), and the fuse (F1) provides circuit protection. With the switch (S1) on the $O N$ position, $\mathrm{T} 1$ and $\mathrm{T} 2$ receive 117 volts AC. Pin 5 feeds 2.5 volts AC to Pin 26 of the NIM-BIN connector and Pin 3 sends 117 volts AC to $\mathrm{Pin} 33$ of the NIM-BIN connector. The unregulated 20 volts at Pin 14 are filtered by C1 and regulated to 12 volts by the voltage regulator

\footnotetext{
*Illustrations follow at end of text.
} 
(VR1). Currents in excess of one ampere can be controlled by VR1 which has a built-in current limiting circuit (VR1 is short-circuit proof). The 12 volts at Pin 16 of the NIM-BIN connector are filtered by $\mathrm{C} 2$. Figure 6 is a component view of the PCB.

\section{OPERATING PROCEDURES}

The following procedures and requirements are recommended for use with the power supply module.

1. Plug module into NIM-BIN.

a. Power requirements:

(1) 117 volts AC

2. Turn on power switch.

3. Check output voltages at front panel test points (TP).

4. Power supply is ready for operation.

\section{SERVICING OF MODULE}

The chart has been included as a troubleshooting guide to assist in the performance of unscheduled maintenance.

\section{Problem}

No +12 volts, DC

No 2.5 volts, $\mathrm{AC}$

No 117 volts, $\mathrm{AC}$

No +12 volts, DC

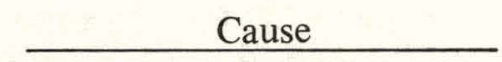

1. Blown Fuse

2. Faulty Switch (S1)

1. Faulty Voltage Regulator

2. Shorted Capacitor (C2)

3. Shorted $\mathrm{C} 1$

4. Faulty Bridge Rectifier (BR1)

5. Faulty Transformer (T1)
FIGURE 1. Front View of Power Module.

17591-1

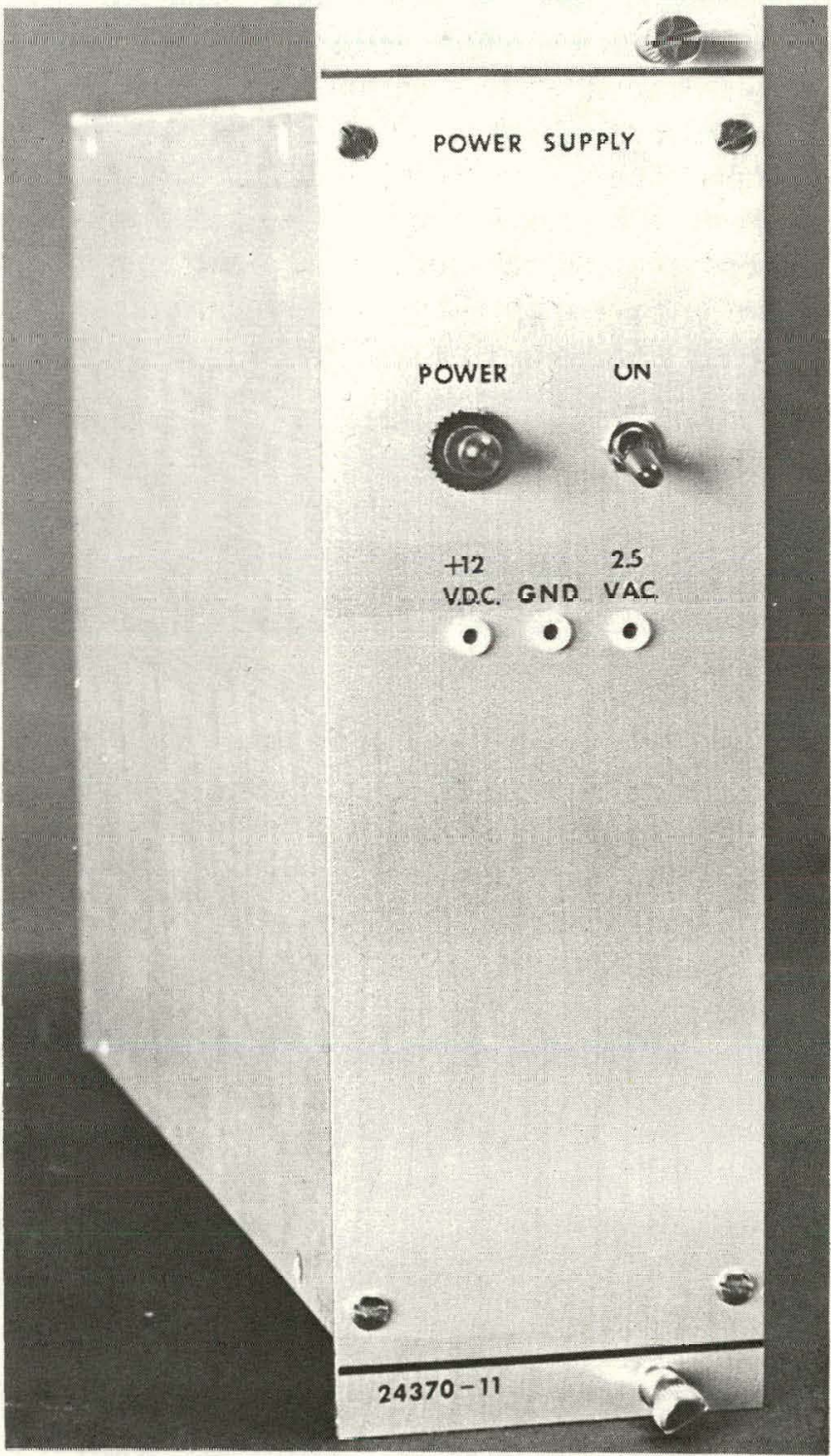


RFP-2303

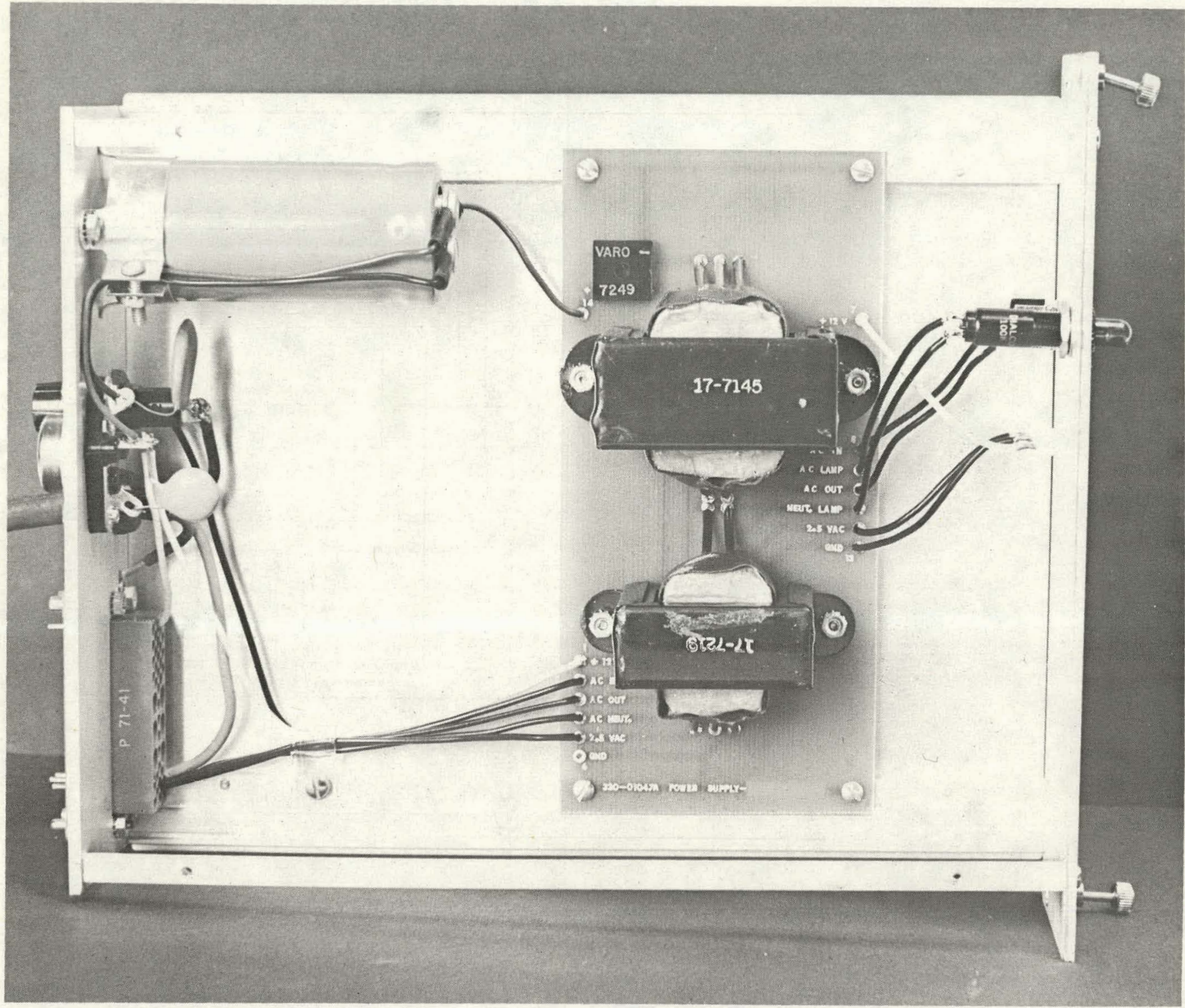

17591-9

FIGURE 2. Interior View of Power Module. 

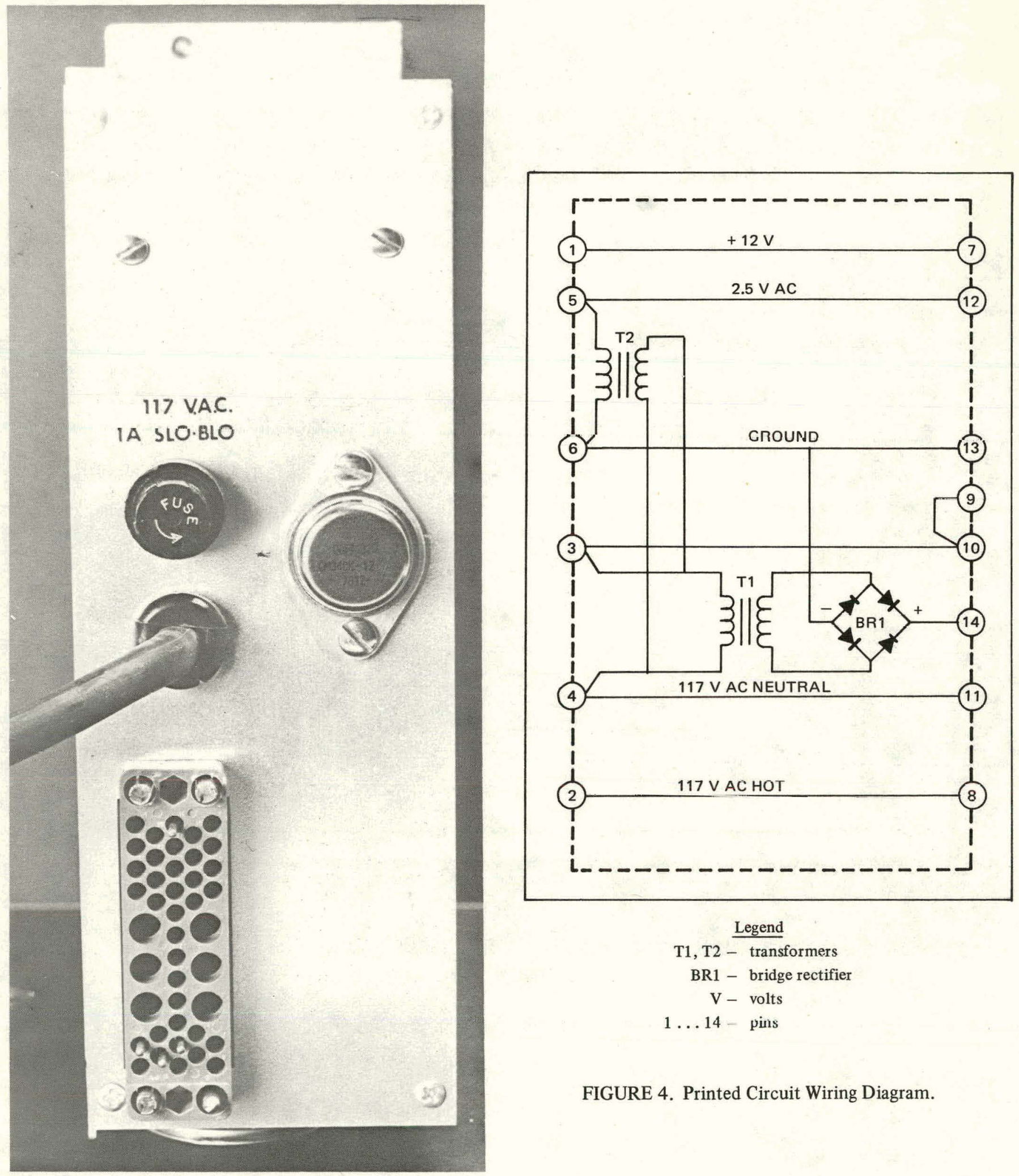

$$
\begin{aligned}
& \frac{\text { Legend }}{\text { transformers }} \\
\text { T1, T2 } & \text { BR1 - bridge rectifier } \\
\mathrm{V} & - \text { volts } \\
1 \ldots 14 & - \text { pins }
\end{aligned}
$$

FIGURE 4. Printed Circuit Wiring Diagram.

FIGURE 3. Rear View of Power Module. 
RFP-2303

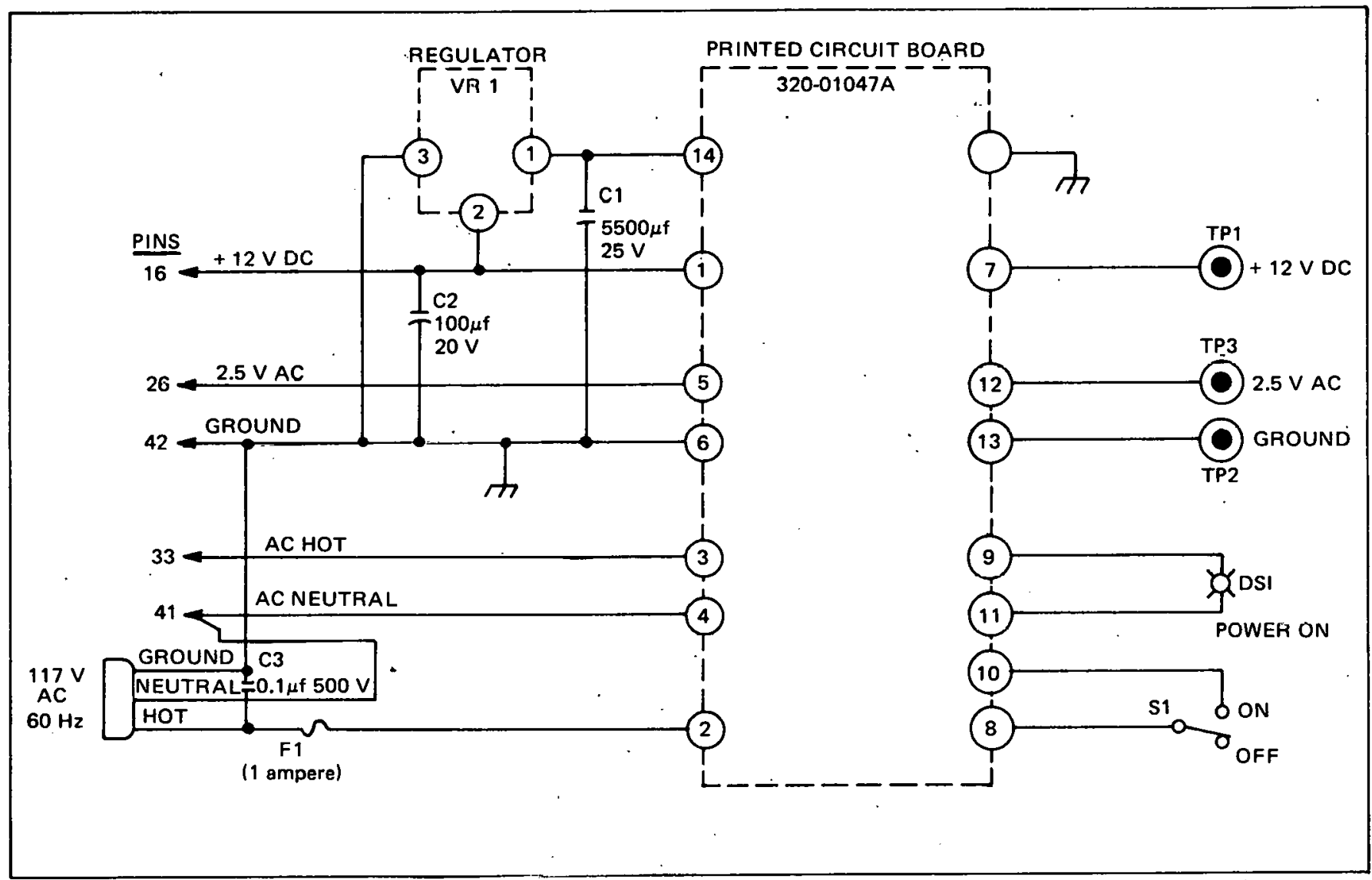

$$
\begin{aligned}
& \underline{\text { Legend }} \\
& \text { VR1 } \text { - voltage regulator } \\
& \text { TP1, 2,3 - } \text { test points } \\
& \text { S1 } \text { - switch } \\
& \text { DS1 } \text { lamp indicator } \\
& \text { F1 } \text { - fuse } \\
& \mathrm{C} 1,2,3 \text { - capacitors in microfarads }(\mu \mathrm{C}) \\
& \mathrm{V}-\text { volts } \\
& \mathrm{Hz} \text { - hert7. }
\end{aligned}
$$

FIGURE 5. Power Supply Module Wiring. 


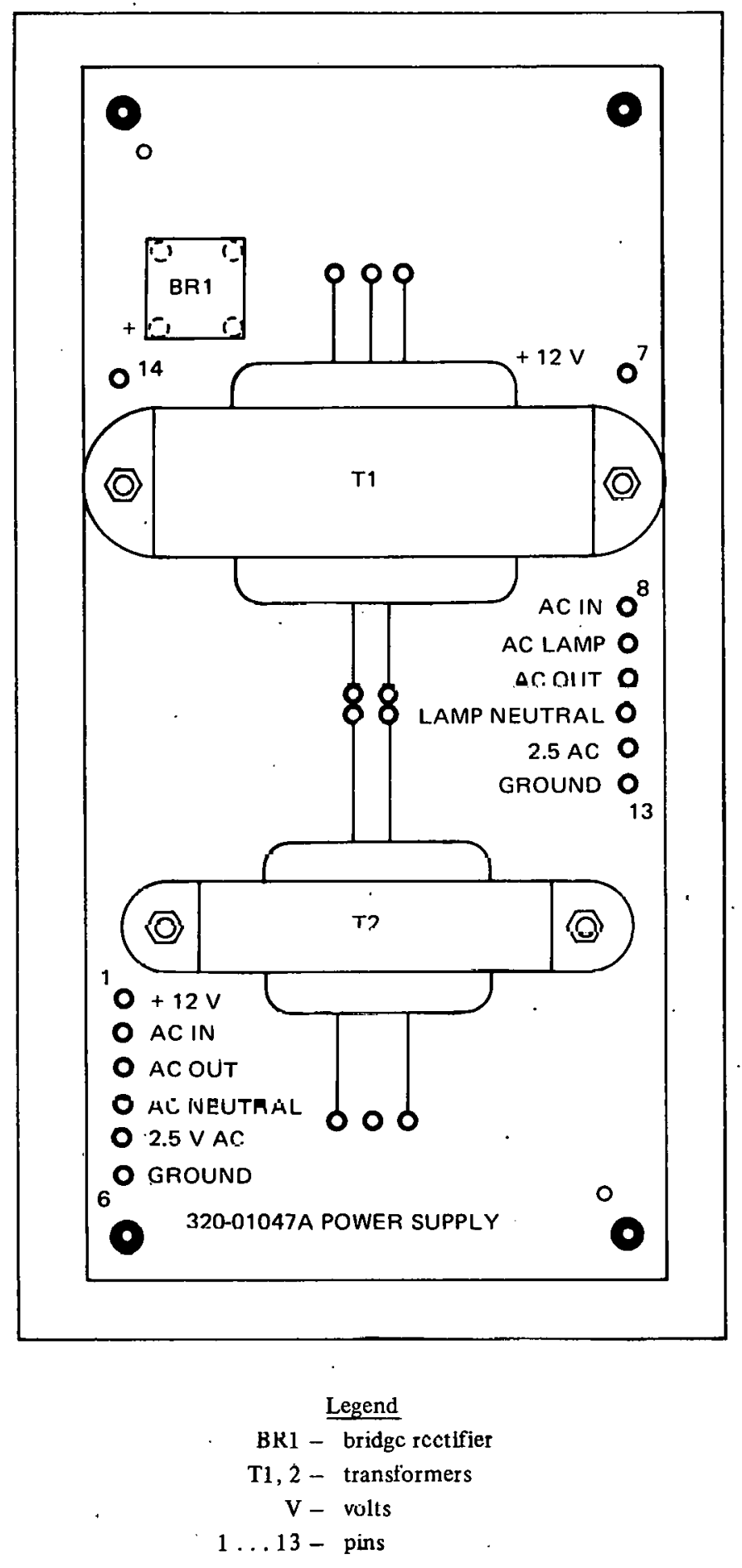

FIGURE 6. Printed Circuit Board Layout. 